\title{
Biomass for energy production characteristics, amount and distribution in Latvia
}

\author{
Janis Kalnacs ${ }^{1}$, Andis Lazdinsh ${ }^{2}$ \\ ${ }^{1}$ State Research Institute "Institute of Physical Energetics", Riga, Latvia, Phone +371 67558782, Fax +371 67558781, \\ e-mail: jkalnacs@edi.lv \\ ${ }^{2}$ Latvian State Forestry Research Institute «Silava» Riga, Phone +371 26595586, Fax +37167901359, \\ e-mail: andis.lazdins@ silava.lv
}

\begin{abstract}
Biomass is one of the largest renewable energy sources in Latvia. Since $54,7 \%$ of the state area is covered by forests, the firewood, wood chips and pellets play a significant role in the heat production, especially at households and municipal heating facilities. Wood chips and pellets are also important export products. Changes in the energy-producing wood export since 1997 are explained. Other kinds of biomass that can be used for heat and electricity production are various agricultural and food production residues, livestock breeding buy-products, sewage sludge, combustible (organic) part of household and industrial wastes, etc.
\end{abstract}

In the present paper, a variety of biomass forms used as the energy sources are analysed. The characteristics of different types of wood biomass and the variations in their parameters are considered. The following determined parameters of biomass are presented: the calorific value, ash content, bulk density, melting point of ashes, sulphur and chlorine content, and others. The biomass energy potential calculated for different regions of Latvia (the data of 2007) is discussed. On the map of Latvia the amount and energy potential of agricultural straw and other biomass for different regions are shown.

Some recommendations elaborated how to improve biomass utilization for heat and electricity production.

\section{Key words}

Renewable energy, woody biomass, parameters, amount, distribution, energy potential.

\section{Introduction}

According to National statistical forest inventory (NFI), total area of forests in Latvia in 2007 was 3.79 mill. ha (57.4\% of the country area) including 3.54 mill. ha of forests with density of trees more than 1000 per ha. But also other kinds of biomass should be taken in account for energy production - various agricultural and food production residues, livestock breeding buy-products, sewage sludge, combustible (organic) part of household and industrial wastes, etc.

\section{Biomass parameters}

The main characteristics of biomass are calorific value, ash content and density, because these parameters determine energy density (Table I).

Table I. - Biomass main parameters, by moisture content $10 \%$

\begin{tabular}{|c|c|c|c|c|}
\hline Nr. & Biomass kind & $\begin{array}{c}\text { Net } \\
\text { calorific } \\
\text { value } \\
\mathrm{kcal} / \mathrm{kg}, \\
\boldsymbol{W}=10 \%\end{array}$ & $\begin{array}{c}\text { Ash } \\
\text { content at } \\
\boldsymbol{W}=10 \%\end{array}$ & $\begin{array}{l}\text { Density, } \\
\mathrm{kg} / \mathrm{m}^{3}\end{array}$ \\
\hline 1 & $\begin{array}{l}\text { Roots of trees } \\
\text { from a bog }\end{array}$ & 3862 & 4.17 & 495 \\
\hline 2 & Reed & & 2.60 & 237 \\
\hline 3 & $\begin{array}{l}\text { Fire wood: } \\
\text { - coniferous trees } \\
\text { - deciduous trees }\end{array}$ & $\begin{array}{l}3730 \\
3580 \\
\end{array}$ & $\begin{array}{l}0.98 \\
0.55\end{array}$ & $\begin{array}{l}600 \\
530 \\
\end{array}$ \\
\hline 4 & $\begin{array}{l}\text { Sawdust without } \\
\text { bark }\end{array}$ & 4177 & 2.31 & 208 \\
\hline 5 & $\begin{array}{l}\text { Sawdust } \\
\text { briquettes } \\
\text { - oak } \\
\text { - coniferous trees } \\
\text { - birch }\end{array}$ & $\begin{array}{l}3952 \\
4150 \\
3859\end{array}$ & $\begin{array}{l}0.26 \\
0.28 \\
0.25\end{array}$ & $\begin{array}{l}658 \\
642 \\
639\end{array}$ \\
\hline 6 & $\begin{array}{l}\text { Raps oil } \\
\text { extrusion } \\
\text { residues } \\
\end{array}$ & 4675 & 6.07 & 583 \\
\hline 7 & $\begin{array}{l}\text { Raps straw } \\
\text { pellets }\end{array}$ & 3643 & 5.25 & 623 \\
\hline 8 & $\begin{array}{l}\text { Bio briquette } \\
\text { from horse } \\
\text { manure with } \\
\text { sawdust } 1: 1\end{array}$ & 3979 & 3.42 & 539 \\
\hline 10 & Wood chips & 4164 & 0.60 & 240 \\
\hline 11 & $\begin{array}{l}\text { Sugar beets, } \\
\text { dryad }\end{array}$ & 3143 & 9.47 & 226 \\
\hline 12 & $\begin{array}{l}\text { Briquettes (peat } \\
+ \text { sawdust } 1: 1 \text { ) }\end{array}$ & 3824 & 3.60 & 740 \\
\hline 13 & Sallow bark & 4037 & 1.36 & 288 \\
\hline
\end{tabular}




\begin{tabular}{|c|c|c|c|c|}
\hline 14 & Wheat straw & 2935 & 2.7 & 228 \\
\hline 15 & $\begin{array}{l}\text { Sunflower shells } \\
\text { pellets }\end{array}$ & 4486 & 5.53 & 581 \\
\hline 16 & $\begin{array}{l}\text { Poultry manure } \\
\text { and litter pellets }\end{array}$ & 2925 & 9.57 & 560 \\
\hline 17 & $\begin{array}{l}\text { Buckwheat } \\
\text { shells }\end{array}$ & 4302 & 2.55 & 204 \\
\hline 18 & Offal pellets & 3620 & 3.61 & 622 \\
\hline 19 & $\begin{array}{l}\text { Wood chips } \\
\text { briquette }\end{array}$ & 4455 & 0.32 & 659 \\
\hline 20 & $\begin{array}{l}\text { Oat shells } \\
\text { pellets }\end{array}$ & 3888 & 3,14 & 541 \\
\hline 21 & $\begin{array}{l}\text { Ray chaff } \\
\text { pellets }\end{array}$ & 3664 & 4,66 & 609 \\
\hline 22 & $\begin{array}{l}\text { Maize corncob } \\
\text { briquette }\end{array}$ & 5794 & 7,97 & 688 \\
\hline 23 & $\begin{array}{l}\text { Grain } \\
\text { - barley } \\
\text { - wheat } \\
\text { - ray } \\
\text { - oat } \\
\end{array}$ & $\begin{array}{l}3708 \\
3638 \\
3380 \\
3624 \\
\end{array}$ & $\begin{array}{l}2,25 \\
1,85 \\
1,50 \\
2,34 \\
\end{array}$ & $\begin{array}{l}548 \\
524 \\
562 \\
513 \\
\end{array}$ \\
\hline 24 & Dry grass & 4666 & 5,48 & 180 \\
\hline 25 & $\begin{array}{l}\text { Biodiesel } \\
\text { production } \\
\text { residue }\end{array}$ & 5575 & 3,72 & 1086 \\
\hline 26 & Peat pellets & 4002 & 2,41 & 639 \\
\hline 27 & Bog peat & 3842 & 7,95 & - \\
\hline 28 & Peat briquette & 3987 & 6,3 & 645 \\
\hline 29 & $\begin{array}{l}\text { Pellets from } \\
\text { wheat straw }\end{array}$ & 3857 & 3,6 & 612 \\
\hline 32 & $\begin{array}{l}\text { Pellets from } \\
\text { deciduous trees }\end{array}$ & 4105 & 0,63 & 595 \\
\hline 33 & $\begin{array}{l}\text { Pellets from } \\
\text { coniferous trees }\end{array}$ & 4212 & 0,27 & 702 \\
\hline 34 & $\begin{array}{l}\text { Sunflower shell } \\
\text { briquettes }\end{array}$ & 4110 & 2,75 & - \\
\hline 35 & $\begin{array}{l}\text { Straw: } \\
\text { - buckwheat } \\
\text { - rape } \\
\text { - rice } \\
\text { - wheat } \\
\end{array}$ & $\begin{array}{l}3807 \\
3802 \\
3816 \\
3838\end{array}$ & $\begin{array}{l}3,5 \\
3,5 \\
4,4 \\
3,6\end{array}$ & - \\
\hline 36 & $\begin{array}{l}\text { Shells: } \\
\text { - oat } \\
\text { - rice } \\
\end{array}$ & $\begin{array}{l}3645 \\
3700\end{array}$ & $\begin{array}{l}7,2 \\
4,8\end{array}$ & - \\
\hline
\end{tabular}

In the table 1 are collected average values of measured parameters, calculated to moisture content $10 \%$, because near this moisture content biomass often is dried. Is possible significant deviations from this average value. Unfortunately energy density for biomass is always low, and this cause logistic problems and necessity to use very different technologies for effective production of energy. For different technologies there are important also different parameters of biomass.

Ash melting behaviour in oxidizing atmosphere is important parameter by selection of incinerating technologies for production of energy from biomass.

In the Table 2 are collected data for ash melting points for popular biomass
Table II. - Ash melting behaviour in oxidizing atmosphere

\begin{tabular}{|l|c|c|c|c|}
\hline \multicolumn{1}{|c|}{ Material } & $\begin{array}{c}\text { Ash } \\
\text { melting } \\
\text { point, } \\
\text { DT } \\
{ }^{\circ} \mathrm{C}\end{array}$ & $\begin{array}{c}\text { Spherical } \\
\text { temper., } \\
\text { ST, }{ }^{\circ} \mathrm{C}\end{array}$ & $\begin{array}{c}\text { Hemisphe } \\
\text { rical } \\
\text { temper., } \\
\text { HT, }{ }^{\circ} \mathrm{C}\end{array}$ & $\begin{array}{c}\text { Flow } \\
\text { temper., } \\
\text { FT, }{ }^{\circ} \mathrm{C}\end{array}$ \\
\hline Buckwheat & 1000 & 1060 & 1080 & 1200 \\
\hline Maize & 1100 & 1180 & 1200 & 1250 \\
\hline Rape & 1250 & 1290 & 1300 & 1400 \\
\hline Wheat & 1280 & 1290 & 1300 & 1390 \\
\hline $\begin{array}{l}\text { Wheat } \\
\text { grains }\end{array}$ & 950 & 1100 & 1200 & 1250 \\
\hline Peat & 1200 & 1250 & 1280 & 1300 \\
\hline Rye & 1150 & 1230 & 1250 & 1300 \\
\hline $\begin{array}{l}\text { Wood } \\
\text { pellets } \\
\text { (Industrial) }\end{array}$ & 1250 & 1290 & 1300 & 1400 \\
\hline $\begin{array}{l}\text { Wood } \\
\text { pellets } \\
\text { (for indivi- } \\
\text { duals) }\end{array}$ & 1300 & 1350 & 1450 & 1500 \\
\hline $\begin{array}{l}\text { Wood chips } \\
\text { (with bark } \\
\text { and impu- } \\
\text { rities ) }\end{array}$ & 950 & 1020 & 1200 & 1250 \\
\hline Wood bark & 1000 & 1060 & 1150 & 1200 \\
\hline
\end{tabular}

Ash melting behaviour of biomass is important, but not limiting factor for using the biomass for energy production. Must be used only appropriate technology. Of course, the biomass parameters important for biogas productions are different from such, for incineration or thermogasification. For example biogas production needs the appropriate proportion between carbon $\mathrm{C}$ and nitrogen $\mathrm{N}$ in row materials. Typical proportions in Latvian raw materials can see in table III [7]. The optimal proportion for good gas production process is $\mathrm{C}: \mathrm{N}=$ $15 \div 20: 1$.

Table III. - Proportions between N and C in different raw materials for bio-gas.

\begin{tabular}{|l|c|}
\hline \multicolumn{1}{|c|}{ Material } & N: C proportion \\
\hline Pig manure & $4 \div 15$ \\
\hline Caw manure & $9 \div 20$ \\
\hline Horses manure & 25 \\
\hline Silage & 10 \\
\hline Hen manure & $7 \div 15$ \\
\hline Waste from slaughterhouses & 2 \\
\hline Straw & 150 \\
\hline Linen residue & 58 \\
\hline Wet sawdust & 208 \\
\hline
\end{tabular}

Heavy metal and other hazardous substances content in biomass in Latvia is always not large. The typical values for two arts of biomass are done in table IV[8] 
Table IV. - Comparison between wood pellets and straw ash content elements

\begin{tabular}{|c|c|c|}
\hline Element & $\begin{array}{c}\text { Wood pellets, } \\
\text { mass \% }\end{array}$ & $\begin{array}{c}\text { Straw ash, } \\
\text { mass } \%\end{array}$ \\
\hline $\mathbf{A l}$ & 3.5 & $0,8-2$ \\
\hline $\mathbf{A s}$ & 0.0002 & $0,001 \div 0,0015$ \\
\hline $\mathbf{B a}$ & 0.098 & $0.01 \div 0,05$ \\
\hline $\mathbf{C a}$ & 19.5 & $5.7 \div 7$ \\
\hline $\mathbf{C d}$ & 0.0001 & $<0.0001$ \\
\hline $\mathbf{C l}$ & 0.02 & $0.4 \div 0,9$ \\
\hline $\mathbf{C r}$ & 0.045 & $0.003 \div 0,007$ \\
\hline $\mathbf{C u}$ & 0.009 & $0,001 \div 0.05$ \\
\hline $\mathbf{F e}$ & 1.6 & $0.2 \div 0,4$ \\
\hline $\mathbf{H g}$ & $<0.0002$ & $<0.0001$ \\
\hline $\mathbf{K}$ & 4.3 & $17 \div 25$ \\
\hline $\mathbf{N i}$ & 0.004 & $0.001 \div 0,0015$ \\
\hline $\mathbf{P}$ & 1.1 & $3.0 \div 4,5$ \\
\hline $\mathbf{P b}$ & 0.0012 & $0.013 \div 0,015$ \\
\hline $\mathbf{S}$ & 0.77 & $2,5 \div 3,5$ \\
\hline $\mathbf{S i}$ & 15.0 & $0,5 \div 1,2$ \\
\hline $\mathbf{S r}$ & 0.035 & $0.05 \div 0,06$ \\
\hline $\mathbf{V}$ & 0.011 & $0.003 \div 0,005$ \\
\hline $\mathbf{Z n}$ & 0.0077 & $0.04 \div 0,15$ \\
\hline $\mathbf{T i}$ & 0.015 & $0.003 \div 0,007$ \\
\hline $\mathbf{Z r}$ & 0.0137 & $0.01 \div 0,15$ \\
\hline
\end{tabular}

\section{Woody biomass}

Total stock of timber in forests in Latvia according to NFI is 654.2 mill.m3 $\left(172.7 \mathrm{~m}^{3} /\right.$ ha in average). Timber stock in the state forests (about $50 \%$ of the total forest area) is considerably higher than in private forests, respectively, 234 and $187 \mathrm{~m}^{3} / \mathrm{ha}$. The most of the forests are $31 \div 60$ years old. These forests also characterizes with the highest annual increment (Figure 1). The highest growing stock is pre-mature and mature forest stands (Figure 2). Average increment of timber volume in 2008 was $8.0 \mathrm{~m} 3$ ha-1 (25.6 mill. $\mathrm{m} 3$ annually). Annual increment by specie is shown in Figure 3.

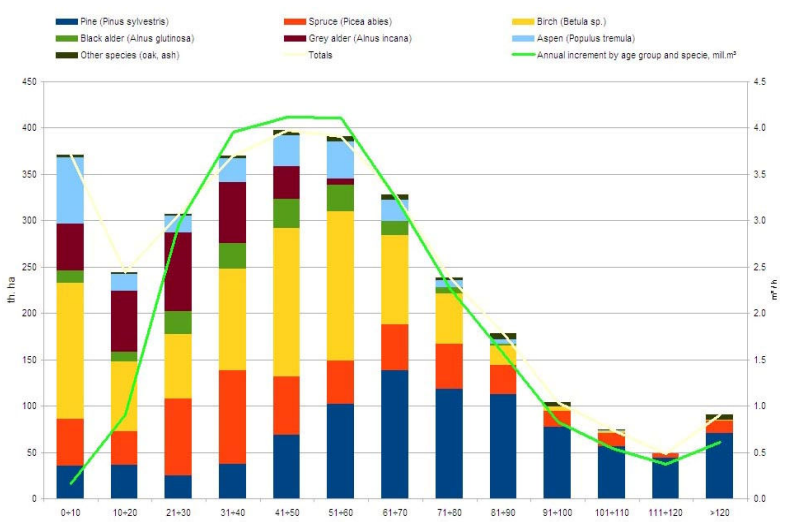

Fig. 1. Forest area by age group and specie

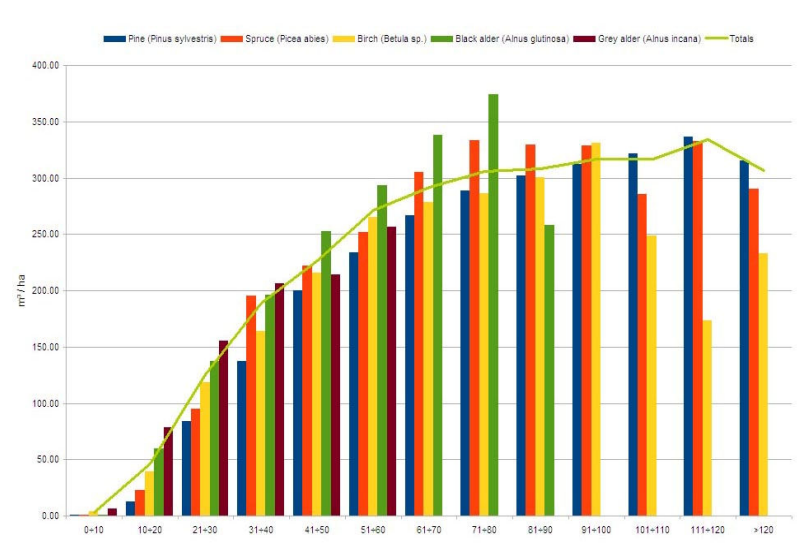

Fig. 2. Growing stock by age and specie

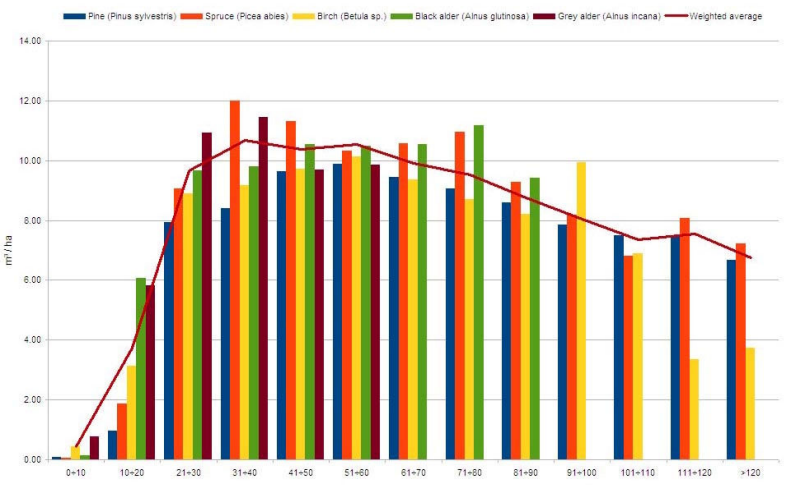

Fig. 3. Annual increment (over bark) by age group and specie

Commercial harvesting of timber increased from 5 mill. $\mathrm{m}^{3}$ in 1990 to 10 mill. $\mathrm{m}^{3}$ annually in recent years. Information about harvesting in 2007 is analysed in this article because it represents the situation in forest sector better than later years. In 2007 total harvesting stock was 9.8 mill. $\mathrm{m}^{3}$ (harvested area 132 th.ha), including 4.4 mill. $\mathrm{m}^{3}$ (67 th.ha) in the state forests and 5.4 mill. $\mathrm{m}^{3}$ in private forests (65 th.ha). 8.1 mill. $\mathrm{m} 3$ (harvested area 38 th.ha) were produced in clear-cuts, 1.7 milj. $\mathrm{m}^{3}$ (94 th.ha) in other cuts. Average harvesting stock was $74 \mathrm{~m}^{3} /$ ha $\left(66 \mathrm{~m}^{3} /\right.$ ha in state forests and $82 \mathrm{~m}^{3} /$ ha in private forests), including $211 \mathrm{~m}^{3} /$ ha in average in clear-cuts $\left(267 \mathrm{~m}^{3} / \mathrm{ha}\right.$ in state forests and $182 \mathrm{~m}^{3} /$ ha in private forests). Potential resources of forest biomass for energy production in Latvia are evaluated in several studies, [1\%6]. Information about forest energy potential in this article is based on the above mentioned studies.

The evaluation of forest biomass resources in Latvia demonstrates that total potential of forest biofuel according to the commercial harvesting structure in 2007 and is 3.8 mill.t in calculation to absolutely dry mass, including 3.2 mill.t of resources fitting to the sustainability criteria. However it should be taken in account that all firewood is assumed to be sustainable, because it is a by-product of commercially more valuable roundwood assortments. Technically available resources are 2.4 mill. $t$ annually. Age structure of forests in Latvia is not uniform and considerable area of forests will reach harvesting age in next decade. Maintaining current approaches in forest management (business as usual) will increase yearly harvesting stock up to about 15 mill. $\mathrm{m}^{3}$ (by $50 \%$ ), thus increasing availability of forest biomass 
for energy up to 3.6 mill.t yearly. However proper planning is necessary to avoid dropping of harvesting stock after $20 \div 30$ years due to lack of resources.

At this point naturally afforested farmlands may assist, because the most of these lands are covered with young stands of deciduous trees with rather short rotation period (from $30 \div 40$ years for grey alder (Alnus incana (L.) Moench) to $70 \div 80$ years for birch (Betula pendula Roth)).Results of the first cycle of the NFI shows that the total area of afforested farmlands in Latvia is 451 th.ha, including 56 th.ha of lands afforested before 1990 and 395 th.ha of lands afforested after 1990. The lands afforested after 1990 are divided into forest lands, where stand characteristics cannot be determined (149 th.ha) because average height of trees of the dominant specie is less than $2 \mathrm{~m}$ and areas with trees of the dominant specie are taller than $2 \mathrm{~m}$ (246 th.ha). The first group of lands afforested after 1990 can be characterized as a "grey area", because land use type can be easily changed to grassland by cutting grass and small trees, but next year, after regrowth of trees, these areas again fits to the forest definition. Total growing stock of timber on the afforested farmlands is 4.3 mill. $\mathrm{m}^{3}$, total aboveground biomass, including undergrowth - 3.2 mill.t of dry matter, annual increment of timber -349 th. $\mathrm{m}^{3}$. The most common species are birch, grey alder and pine (Pinus sylvestris L).

Three management alternatives are considered for afforested farmlands - change of land use type, reconstruction of stands and management of existing stands. Moving to other land use type can be done in 149 th.ha, where trees are small and removal of woody vegetation is simple. Reconstruction of stand by replacing growing specie is recommended for 212 th.ha, where density of stand is less than critical. It would release 815 th.t of biomass suitable for bioenergy applications. Thinning can be done in 52 th.ha, releasing at maximum 941 th. $t$ of biomass excluding undergrowth. No management activities are necessary in 37 th.ha.

Total sustainable potential of intensification of production of forest biofuel in Latvia corresponds to 5 mill. MW.h of primal energy yearly without further increase of the yearly harvesting stock. Share of different sources of woody biomass is shown in Figure 4. The business as usual potential for the next decade is about 7.5 mill. MW.h yearly. The most significant potential resources are stumps (44\% of currently non-utilized resources), small trees in early thinning (15\%), slash in clear-cut (14\%) and management of afforested farmlands (13\% of non-utilized resources). However, the most of technically available resources, excluding stumps and woody vegetation on farmlands are not accessible due to a high production costs and limited knowledge about silvicultural consequences of intensification of forest biofuel extraction. Therefore considerable research and development efforts are necessary to reduce costs of production and to secure sustainability of forest management.

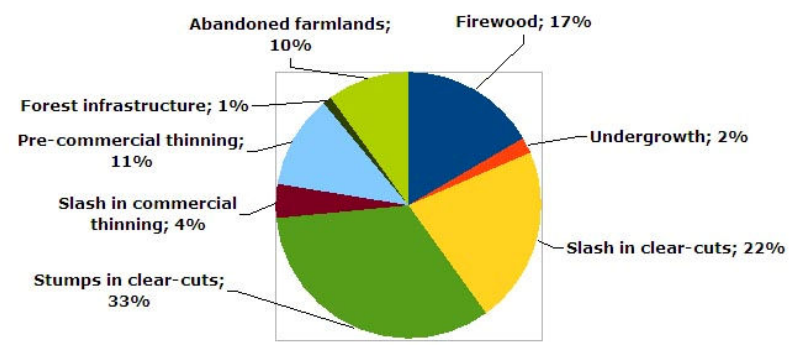

Fig. 4. Potential of different woody biomass resources

\section{Other biomass}

Energy potential of other kinds of biomass is lower in compare to the forests biomass, but in the different regions of Latvia, for example for Zemgale region share of other biomass can be considerably higher in comparison to the forest biomass for energy production. Of course, energy potential depends also from technologies, we are using for energy production

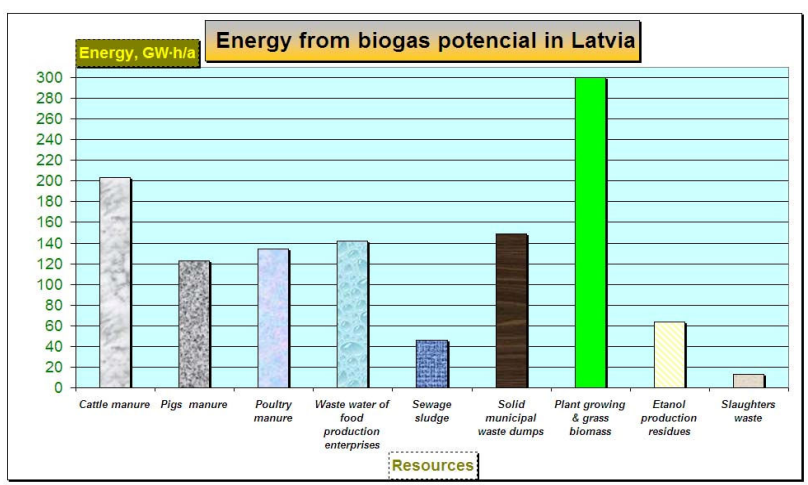

Fig. 5. Potential of energy production from bio-gas

Figure 5 show energy potential, which can be produced from bio-gas, obtained from different stock.

Possible achievable bio-gas energy amount strongly very for different regions of Latvia — fig 6 [9].

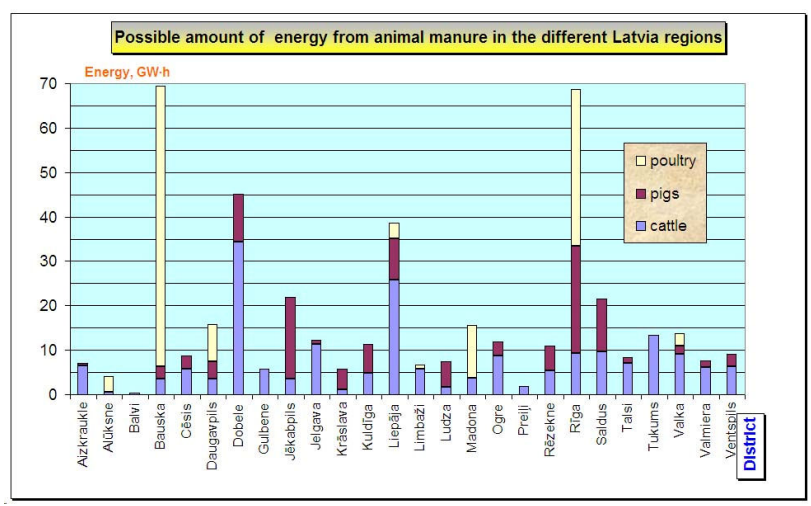

Fig. 6. Achievable bio-gas energy potential in different Latvia regions

Great difference between energy production potential from biomass is in all Latvia districts. As example Fig. 7, show comparison between different biomass art potentials. The is done only one part of forest biomass - local obtained fire wood for one region. 


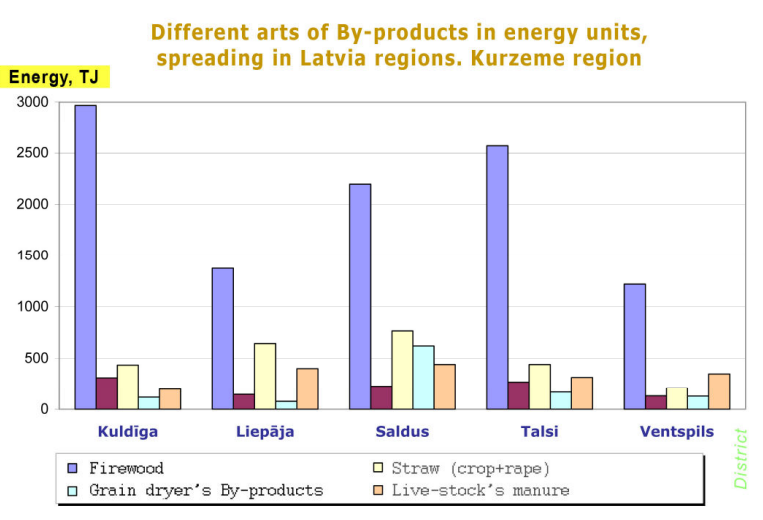

Fig 7. Energy potential of different kinds of biomass in Kurzeme region

For Zemgale regions these proportions are extremely different, Figure 8.

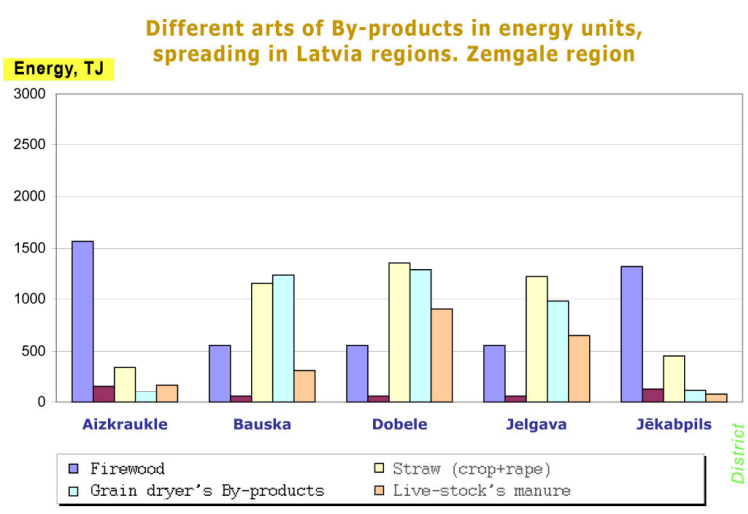

Fig 8. Energy potential of different kinds of biomass, Zemgale region

For better demonstration in Fig.7 and 8 energy potential for agriculture by-products is multiplied 5 times, but for live-stocks -2 times.

From 2005 till 2009 the research about distribution of straw biomass in Latvia was implemented to improve the situation with straw utilisation for heat and electricity production. The recommendation how to rich desirable results are elaborated within the scope of this study.

Till now key obstacles, why straw energy potential in Latvia is not used or used insufficiently are:

1. Insufficient information on straw firing for heating and, as a result, a negative attitude of the society.

2. Demonstration of straw firing is insufficient.

3. No local production of small boilers.

4. No economic stimuli for the necessary equipment production and straw utilization as fuel.

5. No access to long-term financing with a real interest.

6. Institutional framework: lack of coordination of straw heating development at the state level.

7. Existence and state of infrastructure meant for connection of straw firing boilers to the heating systems.

Figure 8 show the energy production potential from straw in 2006. What kind of energy can get - electricity, heat or transport fuel, depends from used technology.

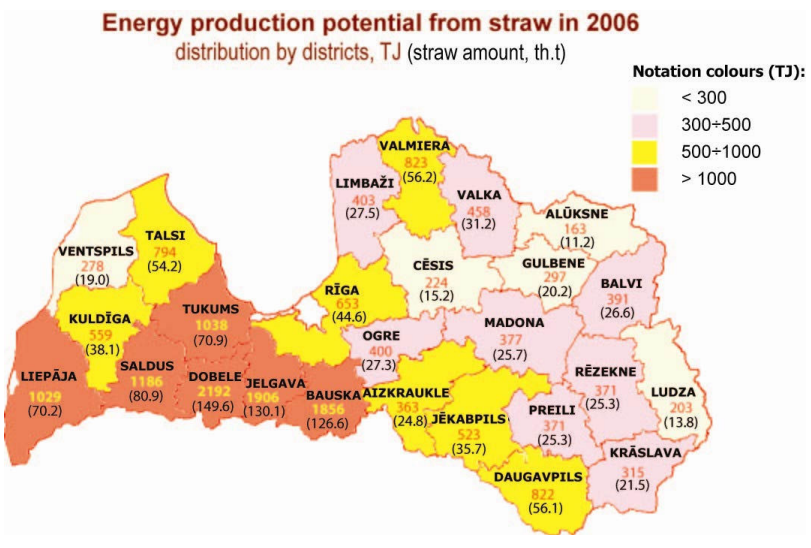

Fig. 8. Energy production potential from straw in 2006

\section{Annual changes in biomass amount}

Annual changes in the availability of biomass as well as bioenergy potential from biomass can be predicted for forest biomass, where annual increment constantly increases due to a proper management and favourable age structure of forests - see Figure 9, but not as easy for other parts of biomass.

\section{a) woody biomass}

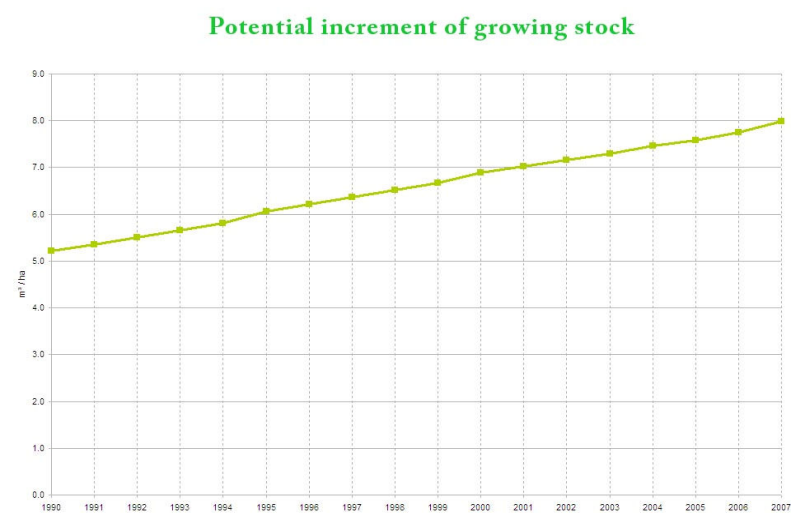

Fig. 9. Potential increment of growing stock

\section{b) other biomass}

The last couple of figures (10 and 11) demonstrates, that amount of agriculture biomass by-products, and corresponding bioenergy potential grows very slowly. Owing to economic crisis this potential today is near the same, as it was in 1906. 


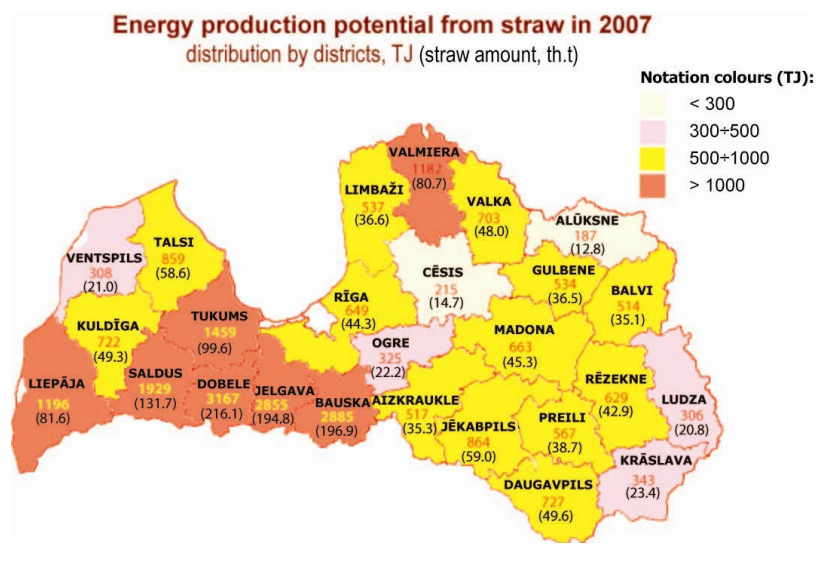

Fig. 10. Energy production potential from straw in 2007

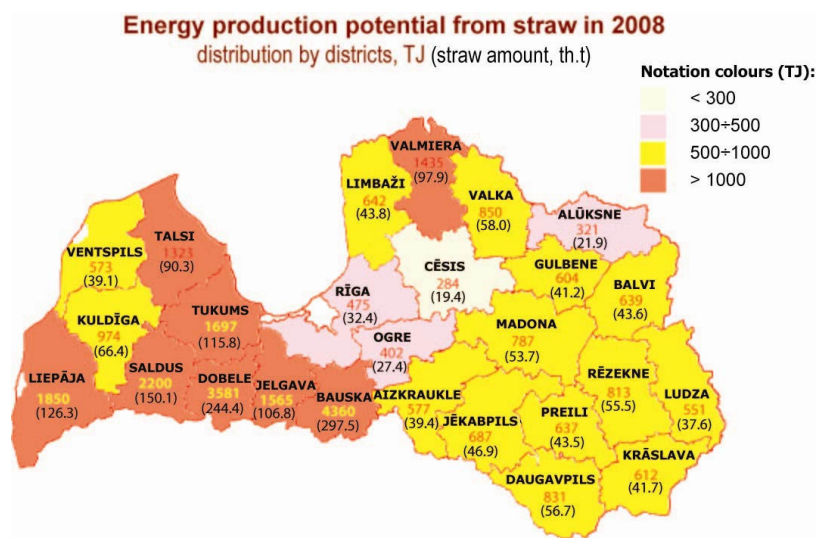

Fig. 11. Energy production potential from straw in 2008

\section{Conclusions}

1. Significant potential of biomass for energy purposes is only one reason to use it for heat and electricity production. Other reasons are:

- relatively rapidly decreased price of the energy obtained from biomass in comparison to energy from fossil fuels;

- increased energy independence;

- potential to reduce greenhouse gas emissions;

- reasonable use of natural resources;
- financial benefits for farmers and forest owners from agricultural and forestry by-products;

- alternative options for development of rural regions.

2. Biomass is regional resource of energy and can play significant role in local energy balance.

3. Deliveries of biomass for bioenergy are easily predictable and well known for increase in case woody biomass, but it is not a case for other kinds of biomass.

4. There is considerable potential for increase of biofuel and bioenergy market in Latvia, development of conversion technologies should be boosted at the same time to utilize fuel in the most efficient way.

\section{References}

[1] Lazdāns V., Lazdinš̌ A. (2006), (Assessment of energy wood resources, harvesting technologies and costs in 20-40 years old forest stands, research report

[2] Thor M., Berndt N., Von Hofsten H., Lazdāns V., Lazdinš A., Zimelis A. (2008), Production of biofuel from precommercial and commercial thinning, forest infrastructure vegetation, undergrowth trees and stumps assuming economical, technological, environmental and silvicultural issues, research report.

[3] Lazdāns V., Zimelis A. (2008), Evaluation of resources of biomass in forest infrastructure, research report.

[4] Lazdiņš A., Liepiņš K., Daugaviete M., Lazdiṇa D. (2007), Development of criteria forefficient management of naturally afforested farmlands, reseach report.

[5] Lazdiņš A., Liepiņš K., Zariņš J., Nartiša M., Liepiṇš J., Bāders E. (2008), Development of criteria for estimation of resources and energy wood production in mechanized precommercial thinning ,of naturally afforested farmlands, research report.

[6] SIA «Vides projekti», LVMI Silava, LLU (2009), Application of sustainability criteria of biofuel and elaboration of action plan, research report.

[7] J.Kalnačs, A.Orupe, D.Grigale, A.Murashov, V.Grekhov. Environmental and energy aspect of stow

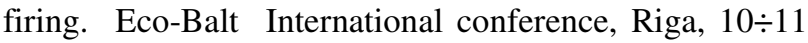
of May 2007.

[8] V.Dubrovskis, U. Viesturs. Fermentation of agriculture waste. Riga 1988.

[9] A.Adamovics, V. Dubrovskis, I. Plume Biogas yield from energy crops in Latvia. 17.European Biomass conference $29.06 \div 3.07$ 2009. Hamburg. 